decreased. The effect of etretinate on her amyloidosis possibly depends therefore on the anti-inflammatory activities of retinoids recently reviewed by Orfanos and Bauer ${ }^{3}$; inhibition of the mobility of granulocytes and their migration into the epidermis, reduction of DNA synthesis of human lymphocytes, and stimulation of monocytes and macrophages-inflammatory cells considered to be essential in the pathophysiology of psoriasis.

1 Dicken CH. Retinoids: a review. I Am Acad Dermatol 1984:4:541-51.

2 Fuchs E, Green $H$. Regulation of terminal differentiation of cultured human keratinocytes by vitamin A. Cell 1981;25:617-25.

3 Orfanos CE, Bauer R. Evidence for anti-inflammatory activities of oral synthetic retinoids: experimental findings and clinical experience. Br $\mathcal{F}$ Dermatol 1983;109:55-60.

4 Plewig G. Wagner A. Anti-inflammatory effects of 13-cis-retinoid acid. Arch Dermatol Res 1981:270:89-94.

Acccepted 23 7une 1986

Departments of Internal Medicine and Dermatology, University Hospital, S-751 85 Uppsala, Sweden

EVA AF EKENSTAM, MD, registrar in rheumatology

GERD MICHAËLSSON, MD, PHD, associate professor of dermatology

ROGER HÄLLGREN, MD, PHD, associate professor of internal medicine

Correspondence to: Dr Eva af Ekenstam, Section of Rheumatology, Department of Internal Medicine, University Hospital, S-751 85 Uppsala, Sweden.

\section{Pancreatitis induced by oestrogen in a patient with type I hyperlipoproteinaemia}

Type I hyperlipoproteinaemia (familial hyperchylomicronaemia) is a disorder in the catabolism of triglyceride rich particles caused by a genetic deficiency of lipoprotein lipase or its cofactor apolipoprotein CII. Pancreatitis is a frequent and dangerous complication. We report on a patient with this disorder who suffered from pancreatitis during the use of an oral contraceptive.

\section{Case report}

The 25 year old patient had undergone laparotomy because of a chyloperitoneum at the age of 6 weeks. At that time milky serum, hepatosplenomegaly, and a chylothorax were found. A fat restricted diet was prescribed, and she grew up normally with no complaints. Serum cholesterol concentrations varied between 5 and $8 \mathrm{mmol} / \mathrm{l}(193-309 \mathrm{mg} / \mathrm{dl})$ and serum triglyceride concentrations between 10 and $30 \mathrm{mmol} / \mathrm{l}(885-2655 \mathrm{mg} / \mathrm{dl}$ ) (figure).

Between the ages of 22 and 25 she was admitted to the hospital eight times because of pancreatitis, indicated by raised amylase activity in plasma and urine. Serum triglyceride concentrations up to $30-40 \mathrm{mmol} / \mathrm{l}(2655-3540 \mathrm{mg} / \mathrm{dl})$ were found, but these may be underestimations because on several occasions concentrations were measured only on the second or third day after admission. During

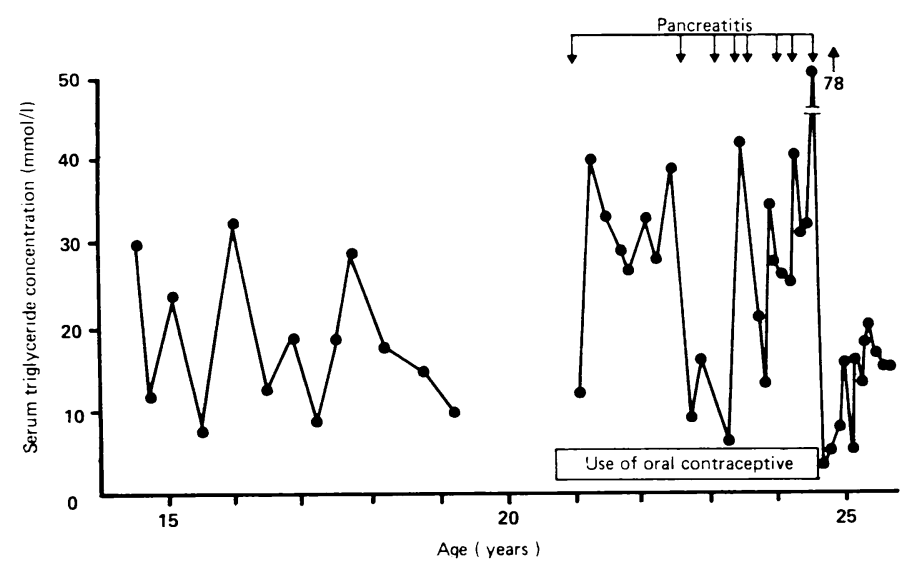

Serum triglyceride concentrations and attacks of pancreatitis in patient with type I hyperlipoproteinaemia.

Conversion: SI to traditional units-Serum triglyceride: $1 \mathrm{mmol} / \mathrm{l} \approx 88.5 \mathrm{mg} / \mathrm{dl}$. the last attack of pancreatitis abdominal abscesses were found during a laparotomy.

After recovery the patient was referred to our clinic. She said that she followed a low fat diet and denied using ethanol. Until three months previously, however, she appeared to have been using an oral contraceptive containing $150 \mu \mathrm{g}$ levonorgestel and $30 \mu$ g ethinyloestradiol, from the age of 21 to 25 years. There was no xanthomas. Liver and spleen were not palpable and blood glucose concentrations were normal. Fasting serum cholesterol concentration was 2.56 $\mathrm{mmol} / \mathrm{l}(99 \mathrm{mg} / \mathrm{dl})$ and triglyceride concentration $4 \cdot 16 \mathrm{mmol} / \mathrm{l}(368 \mathrm{mg} / \mathrm{dl})$. High density lipoprotein cholesterol concentration was $0.42 \mathrm{mmol} / 1(16 \mathrm{mg} / \mathrm{dl})$. Lipoprotein lipase activity was selectively measured in postheparin plasma ( 50 $\mathrm{U} / \mathrm{kg}$ ) after inactivation of hepatic lipase by specific antiserum. ${ }^{2}$ Lipoprotein lipase activity and hepatic lipase activity were 0.3 and $6.6 \mu \mathrm{mol}$ of free fatty acids $\mathrm{ml} / \mathrm{h}$, respectively (mean (range) values for 15 normal women $8 \cdot 9(5 \cdot 8 \cdot 14 \cdot 1)$ and $16 \cdot 2(6 \cdot 5-27 \cdot 4) \mu \mathrm{mol} / \mathrm{ml} / \mathrm{h}$, respectively). On isoelectric focusing of very low density lipoproteins a normal amount of apolipoprotein CII was found. ${ }^{2}$ Because the attacks of pancreatitis seemed to be related to the use of the oral contraceptive, its use was discouraged. During one year of follow up serum triglyceride concentrations dropped, and the patient remained free of abdominal complaints (figure).

\section{Comment}

Pancreatitis is a common manifestation in familial hyperchylomicronaemia and may be induced by insufficient adherence to a low fat diet or by pregnancy leading to very high serum triglyceride concentrations. ${ }^{1}$ The very high concentrations of plasma triglycerides during pregnancy are supposed to result from an increased hepatic secretion of very low density lipoprotein under the influence of oestrogen in addition to the impaired clearance of these particles from the blood. ${ }^{1}$ Oral contraceptives containing oestrogen may have the same effect. In the normal population oral contraceptives also increase serum triglyceride concentration. ${ }^{3}$ In other forms of familial hypertriglyceridaemia pronounced hyperlipidaemia and pancreatitis have also been associated with use of oral contraceptives ${ }^{45}$; however, such an association has not yet been reported in patients with type I hyperlipoproteinaemia.

Our patient had no problems when following a low fat diet, but when she started to use an oral contraceptive her hyperlipidaemia was aggravated and bouts of severe pancreatitis occurred. These drugs should therefore not be prescribed in patients with familial hyperchylomicronaemia and distinct hypertriglyceridaemia.

We thank Dr R Estourgie and Dr J Wils for providing clinical data. We also thank Mrs P van Heijst and H Hak-Lemmens for technical help and Mrs A Ruesen for preparing the manuscript.

1 Havel RJ, Goldstein JL, Brown MS. Lipoproteins and lipid transport. In: Bondy PK, Rosenberg LE, eds. Metabolic control and disease. Philadelphia: Saunders, 1980:393-494.

2 Stalenhoef AF, Casparie AF, Demacker PN, Stouten JT, Lutterman JA, van 't Laar A. Combined deficiency of apolipoprotein C-II and lipoprotein lipase in familial hyperchylomicronemia. Metabolism 1981;30:919-26.

3 Wallace RB, Hoover J, Barrett-Connor E, et al. Altered plasma lipid and lipoprotein levels associated with contraceptive and oestrogenic use. Report from the Medications Working Group of the Lipid Research Clinics Program. Lancet 1979;ii:111-5.

4 Glueck CJ, Scheel D, Fishback J, Steiner P. Estrogen induced pancreatitis in patients with previous covert type V hyperlipoproteinemia. Metabolism 1972;21:657-66.

5 Davidoff F, Tishler S, Rosoff C. Marked hvperlipidemia and pancreatitis associated with contraceptive therapy. N Engl f Med 1973;289:552-5.

Accepted 11 fuly 1986

Division of General Internal Medicine, Department of Medicine, University of Nijmegen, PO Box $9101,6500 \mathrm{HB}$, Nijmegen, Netherlands

$P M$ J STUYT, MD, consultant internist

P N M DEMACKER, PHD, biochemist

A F H STALENHOEF, MD, consultant internist

Correspondence to: Dr Stuyt.

\section{Correction}

Increased risk of sudden infant death syndrome in older infants at weekends

We regret that there was an error in the table in the short report by Murphy, Campbell, and Jones (9 August, p 364). In the right hand column (95\% confidence interval) the entry for Saturday should read $(1 \cdot 02-1 \cdot 16)$. 